Relations industrielles

Industrial Relations

\title{
D.N. ASHTON, J.J. MAGUIRE : Young Adult in the Labour Market. Paper no 55, Leicester, University of Leicester, 1986, 163 pp.
}

\section{Lise Poulin-Simon}

\section{Volume 42, numéro 4, 1987}

URI : https://id.erudit.org/iderudit/050376ar

DOI : https://doi.org/10.7202/050376ar

Aller au sommaire du numéro

Éditeur(s)

Département des relations industrielles de l'Université Laval

ISSN

0034-379X (imprimé)

1703-8138 (numérique)

Découvrir la revue

Citer ce compte rendu

Poulin-Simon, L. (1987). Compte rendu de [D.N. ASHTON, J.J. MAGUIRE : Young Adult in the Labour Market. Paper no 55, Leicester, University of Leicester, 1986, 163 pp.] Relations industrielles / Industrial Relations, 42(4), 887-889. https://doi.org/10.7202/050376ar

Tous droits réservés @ C Département des relations industrielles de l'Université Laval, 1987
Ce document est protégé par la loi sur le droit d'auteur. L’utilisation des services d’Érudit (y compris la reproduction) est assujettie à sa politique d'utilisation que vous pouvez consulter en ligne.

https://apropos.erudit.org/fr/usagers/politique-dutilisation/ 
de s'immiscer dans les prérogatives de la direction et, plus généralement, dans la gouverne de l'économie du pays, ainsi que les réflexions du juge Boulton, de la Australian Conciliation and Arbitration Commission, sur les rôles respectifs du volontariat et des sanctions dans le fonctionnement du système d'arbitrage obligatoire d'Australie.

En bref, selon le résumé d'un avocat du pays, «The Australian Way of Compulsory arbitration is to be preferred to other models, at least for the time being) (p. 192). Le lecteur canadien - celui, en particulier qui voudrait se préparer au congrès mondial de l'Association internationale des relations industrielles, qui aura lieu en Australie en 1992 - pourra, grâce à ces pages, trouver utile d'actualiser ses connaissances générales et préalables du système de rapports du travail qui prévaut en ce pays.

Pierre VERGE

Université Laval

Young Adult in the Labour Market, par D.N. Ashton and J.J. Maguire, Research Paper no. 55, Leicester, University of Leicester, 1986, XIII, 163 pages.

Dans le cadre de son programme de recherche sur l'emploi et les relations industrielles, le ministère de l'Emploi de l'Angleterre a publié cette étude sur les jeunes de 18 à 24 ans, groupe dont l'incidence du chômage est très forte, comme c'est aussi le cas au Canada. Celle-ci a été réalisée par une équipe de recherche de l'Université de Leicester. Elle vise à mieux comprendre le comportement des jeunes sur le marché du travail en identifiant les facteurs qui affectent leur attitude à l'égard de l'emploi, de la mobilité et de la formation.

La théorie économique traditionnelle explique la plus forte incidence du chômage chez les jeunes principalement par des niveaux trop élevés de salaire par rapport à leur productivité et par des comportements d'instabilité sur le marché du travail. La plus forte instabilité résulterait de caractéristiques personnelles, soit une plus faible éthique du travail, soit une place normale d'adaptation au marché du travail par l'expérimentation.

À travers divers types d'emploi, cette thèse sur le chômage des jeunes conduit à des recommandations de politiques entre autres relatives au salaire minimum et à la formation pour améliorer leur productivité.

Une autre thèse, celle de la segmentation des marchés du travail, conduit à des politiques souvent différentes sinon de nature au moins d'application. Selon cette thèse, la plus forte incidence du chômage chez certains groupes démographiques n'est pas surtout le résultat de caractéristiques personnelles inhérentes à cette main-d'oeuvre, mais il est attribuable à des caractéristiques du marché du travail. Celui-ci serait segmenté à cause de pratiques d'embauche et de promotion, de normes institutionnelles et de perceptions des employeurs quant aux capacités de certains groupes démographiques d'occuper certaines filières d'emploi. Les segments du marché du travail auxquels les jeunes ont accès présentent des caractéristiques fort différentes du segment des emplois d'adultes. Ces caractéristiques affectent les comportements et les attitudes des jeunes adultes et expliqueraient leur chômage plus élevé.

Au Canada, les thèses de la segmentation ont surtout alimenté les réflexions sur le marché du travail féminin et ont conduit à des politiques d'action positive. 
L'originalité de cette étude est de se pencher sur la situation des jeunes en Angleterre en tentant de voir si ce sont des caractéristiques personnelles des jeunes ou des caractéristiques du marché du travail, c'est-à-dire la segmentation des marchés, qui exercent une influence déterminante sur leur comportement à l'égard de l'emploi. L'étude s'attarde particulièrement à obtenir un éclairage sur les deux propositions suivantes qui se rattachent à l'une des deux thèses: d'abord les expériences des jeunes adultes dans leurs années initiales sur le marché du travail façonnent-elles les attitudes et les comportements à l'égard de l'emploi et de la formation? Par exemple, les types d'emploi où ils ont été confinés, la mobilité d'emploi, l'expérience de chômage; ensuite, le passage d'une situation de dépendance à la famille d'origine, à une situation d'autonomie et de responsabilité familiale affecte-t-il ces comportements; l'hypothèse étant que l'éthique du travail est plus forte lorsque les responsabilités augmentent.

Pour mieux comprendre ces phénomènes, les chercheurs ont réalisé une étude comparative des caractéristiques du marché du travail pour les jeunes de 18 à 24 ans dans quatre localités anglaises. Celles-ci présentaient des aspects distinctifs quant aux niveaux de chômage et aux structures industrielles et occupationnelles. Une analyse statistique des caractéristiques générales du marché du travail à travers les données du recensement offre un premier portrait des aspects particuliers de chacune des localités. Ensuite, une enquête par échantillonnage est réalisée au cours de l'année 1982-83. Le questionnaire de l'enquête est annexé à l'étude. Des entrevues semi-directives auprès de 450 jeunes de 18 à 24 ans dans chacune des localités et auprès d'un certain nombre d'employeurs permettent de raffiner l'analyse.

Au début de l'enquête, les chercheurs ne s'attendaient pas à ce que les caractéristiques particulières des marchés du travail locaux aient une influence aussi déterminante sur les attitudes et les comportements des jeunes. Leurs analyses comparatives des quatre localités les amènent aux constats suivants: les comportements des jeunes sont largement influencés premièrement par le segment d'emploi dans lequel ils s'engagent lors de leur premier emploi, deuxièmement par la situation de surplus ou de pénurie de main-d'oeuvre dans leur localité et troisièmement, par les différences dans le fonctionnement du marché du travail local.

Comme le soulignent les auteurs, l'importance des différences de fonctionnement des marchés du travail locaux pour expliquer le comportement des jeunes à des implications méthodologiques pour la formulation de projets de recherche futurs. Examiner le fonctionnement du marché du travail à travers des moyennes nationales peut conduire à des conclusions peu réalistes. Il y a aussi des implications au niveau des politiques du marché du travail; pour être efficace, celles-ci doivent pouvoir s'adapter aux besoins locaux. Les résultats de l'étude suggèrent également que si les attitudes des jeunes envers la formation sont largement tributaires des possibilités d'emploi et de mobilité sur le marché du travail local, alors toute amélioration comme toute détérioration du niveau de l'emploi générera des motivations positives ou négatives à l'égard de la formation.

Les premier et deuxième chapitre présentent le cadre de l'étude ainsi que les principaux résultats et recommandations de politiques. Les deux suivants sont d'ordre méthodologique. Les chapitres 5 à 14 analysent les résultats statistiques et ceux de l'enquête selon des thèmes spécifiques, et en examinant dans quelles mesures les caractéristiques personnelles des jeunes ou celles des marchés du travail expliquent le mieux les attitudes et comportements des jeunes. Les thèmes de chacun des chapitres sont: l'origine familiale et les attitudes; la mobilité des jeunes; le niveau de chômage et l'attitude des jeunes; les programmes d'emploi gouvernementaux pour les jeunes; les segments d'emploi et la mobilité; la situation vécue du chômage des jeunes selon les caractéristiques personnelles; les attitudes des jeunes à l'égard de la formation; la situation de l'embauche et les problèmes des jeunes en chômage. 
Cette étude mérite une attention particulière de tous ceux qui s'intéressent au fonctionnement du marché du travail; tant les praticiens que les théoriciens. L'ensemble de ces résultats ne peut évidemment pas être appliqué à la situation québécoise ou canadienne. On doit toutefois en retenir que la thèse de le segmentation offre un éclairage essentiel pour comprendre certaines dysfonctions du marché du travail, surtout dans les pays à niveau de chômage très élevé, comme c'est le cas au Canada. Il serait certainement utile d'examiner la situation du chômage des jeunes au Québec, à travers cette grille d'analyse afin de pouvoir mieux évaluer la pertinence de certaines stratégies actuelles à l'égard de l'emploi des jeunes à chômage chronique. Si la plus forte incidence de chômage et le taux de roulement plus élevé qu'ils connaissent résultent surtout des caractéristiques des segments d'emploi qu'ils occupent, les mesures pour augmenter leur «employabilité» pourraient s'avérer moins efficaces que prévu.

Lise POULIN SIMON

Université Laval

The International Labour Organisation: A Canadian View, by John Mainwaring, Ottawa, Canadian Government Publishing Centre, 1986, xvi, 206 pp.

This is an important book, authored by a person well qualified to write it. The Canadian perspective highlights the discussion of more universal themes. The book is concerned with historical and current matters, and makes sensible suggestions for increasing support, within Canada and globally, for a more effective implementation of the principles for which this U.N. Agency stands. The fundamental approach is educational.

The book is important because of its subject matter. The ILO goals are to improve the conditions of working men and women everywhere, and to promote and protect their right of association as one means to this end. There is little controversy over the organisation's efforts to help workers in developing countries through programs of direct aid, but, as the author notes, the goals «seem to imply a redistribution of wealth, causing problems for people who posess it. And while the right of association in trade unions, a fundamental ILO principle, may be strongly established in some countries, it is accepted only grudgingly in others and is forcibly resisted in many) (p. 1). The setting of standards for labour legislation, and investigations of complaints of failure to comply with agreed ILO standards, may also create tensions within member states.

Both an incisive mind and writing style add to the value of John Mainwaring's work. He has also an intimate first-hand knowledge of his subject. He was a participant at ILO conferences over nearly forty years, frequently as head of the Canadian delegation, and served as Chairman of the ILO Governing Body for a period. He shows his awareness of the blinkers of too close an attachment, and is careful to identify the expression of his personal views from the more impartial judgements which the work requires. The book is not bland: pointed criticism is made where this is seen to be warranted.

Highlighting the Canadian perspective allows more global developments to be seen in sharper focus, and makes it easier for the Canadian reader to relate distant international situations to what is happening in the world more immediately around him. For example, the relative lack of interest in THE ILO within Canada in the 1920's can be related partly to the exigencies of travel, while Canadian participation in events which led to a system of labour standards replacing the founding idea of international labour legislation, was effectively prevented 